\title{
Electron swarm phenomena in SF6+IIe and SF6+Ar mixtures
}

\author{
Sheuhab A, Zcidan, Mathhlis M. Iamail, Duraid F. Mabadi \\ Departnent of Applied Science, Universily of Technology
}

\begin{abstract}
Alsstract

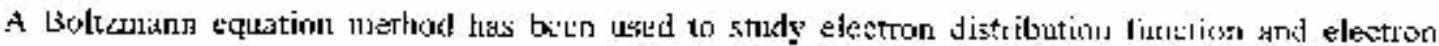

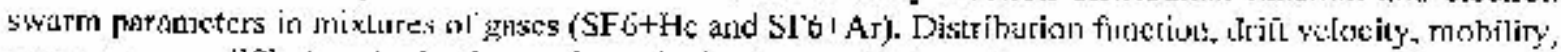

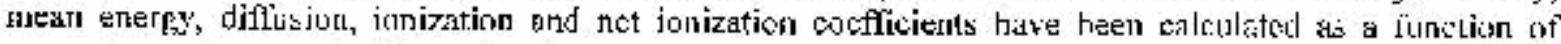

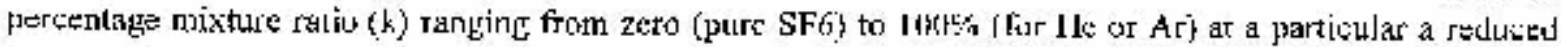

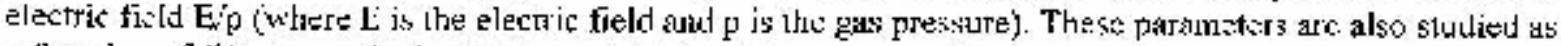

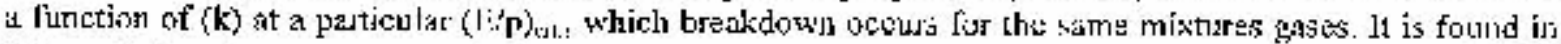

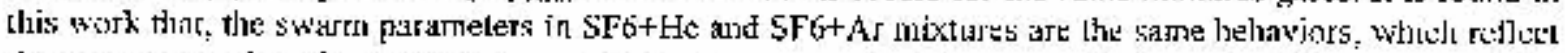

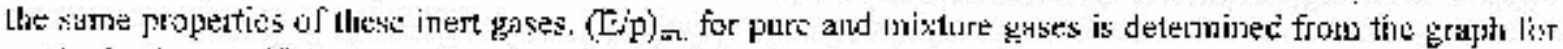

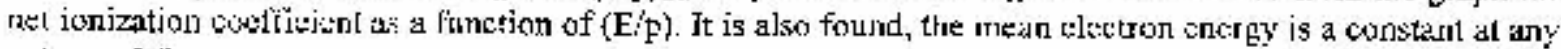

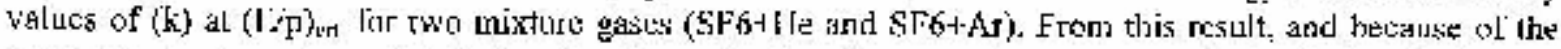
wean conercy tlepenids on distribution funetion vnly, therefore, one important conclusion is the distritulion

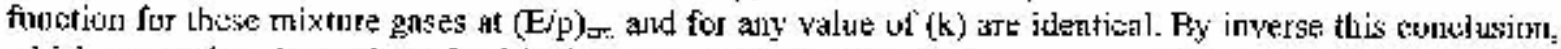

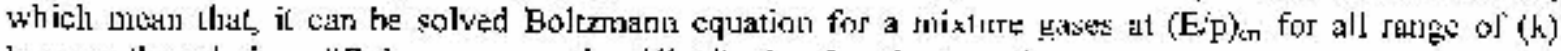
hocauss the solution od' $B$ islominn equatiou (distribution function) are the same.
\end{abstract}

\section{Introduction}

Sulphur hexaflueride, SFta is orae of the nosi inportanc gares for ulse nul unly as electrical insulatimg but alod as mediun for gas lasers and

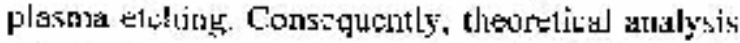
of electron swarm parameters in $51 \% 6$ or its Irixlures is very importaust for predicting electrical propesties of the gas as used in thuse applicationa [I].

Ilelsun und Aryon and mixnures of these twat bouses ace oficn used as filling fir electronic devices such as stabilizing valves, lasers, and spark thidmbers [a.3]. 'Tlu use of' mixture of SFG and a Lherp inert gases coults sliminate some of the problem asseciated with pure slife and reduce the insulation cost $[4,5]$.

Mortizi ancl cring: |6| carried out uniforek field breakdown messurements in $\mathrm{SF} G+\mathrm{Hc}_{\mathrm{c}}$ and $S F \sigma+h r$ mixtures. 'They neted that, as in pure SFG, itl these mixteres tended to tudis a liniting, value or (Eip) Similne to pure STi6 it is unusidered that the vilue $\left(\mathbf{F}^{\prime} \mid\right)_{2 \mathrm{~g}}$ is Juluced when the jontization

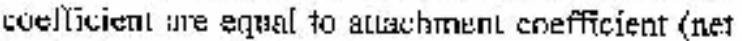
ion'saticon coofficient is zero) Jur a particular unixlure.

All the previous studies, which deal with the solution of Bullzmann equation to predict the distribution furcisos and swam paramelers of mixture gaseti. the reserd arc fuluctions of $(k)$ as a miss inipoctad linetion at a particular E'p.

In the present work, the resules are choses aceuralely, which satisfy the breakduwin triteria anly. Therefore, the swarm paraunelers at breakdowin critcria accul are considered as a

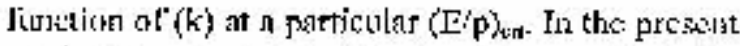
work, it is ads?pted that the hreakdown criltria fur pure eas octurs when a small increasing of (E) due to litrye incretsing ol ionization cosfficicht. The reition of this adopred due to the iorization is aceurulutive prosess. At this mint, all results as deduced.

\section{'Theory of calculation}

The numerical methods used ju llis wurk ar: esitentially the same as those in refertutes $[\overline{7}, 8,9]$. The calculfation is performed over a range of tricrus hetween zero and maximum cticrcy, wherc the electron energy distrikution fiuction is sulfieiently small. Iherefore. the influtule on this results of clection whos cusgles sure atome Hexintur cencrgy may be neslected. The distrihution fundion is salculated by usins BOLSIG program [8] which solving uumerically IBollymann equation for $S F G+H e$ and $\mathrm{SH}^{2} 6+\mathrm{Ar}$ mixtures. The input data of cross-scctions of $\mathrm{SF} g$ are token from [toh[1], while the cross-scetions of le and ht are tnken from[10, ]l]. At the tetud stage. swajm paramcters: are calculated by injecting the resulf al distritution function in the cyuations be[owi $\bar{i}$.

$$
\begin{aligned}
& \frac{\omega_{\mathrm{m}}}{\mathrm{p}}=\left(\frac{2}{\mathrm{~m}}\right)\left[\mathrm{k} \mathrm{i}_{\mathrm{mb}}+(1-\cdots \mathrm{k}) \perp_{\mathrm{m} 2}\right] / w_{\mathrm{m} 1}
\end{aligned}
$$

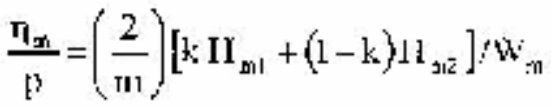




$$
\begin{aligned}
& W_{\mathrm{m}}=\left(\frac{\varepsilon}{3}\right)\left(\frac{2}{\mathrm{ul}}\right)^{i s}\left(\frac{\mathrm{E}}{\mathrm{P}}\right) \mathrm{S}_{\mathrm{m} \mathrm{m}}
\end{aligned}
$$

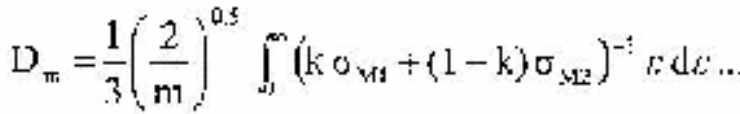

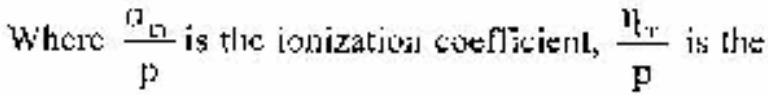
attachment costficient, $W_{\mathrm{E}}^{r}$ is the clectrou drit

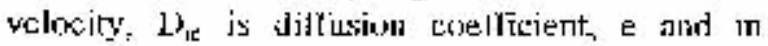
represeril eleutron charge nut electron mass respectively;

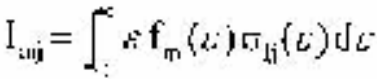

$$
\begin{aligned}
& \mathrm{II}_{\pi \geqslant}-\int \varepsilon \mathrm{f}_{\mathrm{r}}(\varepsilon) \sigma_{<}(\varepsilon) \mathrm{d} \varepsilon
\end{aligned}
$$

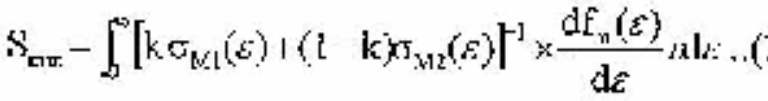

Where, $\mathrm{i}=1,2, \sigma_{\mathrm{rj}}, \sigma_{\mathrm{Aj}}, \sigma_{\mathrm{i} \mathrm{j}}$ are ionizarion, attinchnent ants retormentum. cross-sections

respecrively, ${ }_{\mathrm{t}}$ : is ionization entergy and $\boldsymbol{f}_{\mathrm{m}}$ is a distrihutina tunction for irixlure gases.

Jiese equations are solved by tumbrital by using MATLAF prougurs. The present calculation is carried out viarying $F / p$ from $5 \mathrm{~V} /$ (com.lurr) to

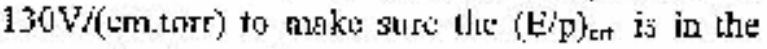
ranges for these rrix lute gases.

\section{Kesult and Discussion}

Hughes[12] shots that the elactron ensury djstriburtion tilection for $\mathrm{Hc}$ at a defurite lis strills pery much loward high energy in comparison with Itat lor SF6 which shows lay Itoll[1 i] at Ute salue valuc of teip. it is sluwn fom Fig (l), the basic molccular properties of the individual gases similarly affect the distributive funclies in gas mixnues. Fingl a,b and c) show that, the distribution function of $\mathrm{Hc}$ and $\mathrm{Ar}$ at dillerent values of $E$ 'p are shifted very much toward not high coesgy as a result of Hughes [13]: but toward low energy in comparison with that for $\mathrm{SF} 6$ (Fig|ค). Fig. $(1<, 1)$ show that the distribution function in $S F 6$ is very large vnlue than for $\mathrm{Hc}$ and $\mathrm{Ar}$ at low energes, whij:l rillew vory strong attachment and viturutional cross-sections, at the sane E'p and lower uffuc at higl encrgies, which reflect very hiph extitatiun und junizition cross-sections.

Hifin.(2 and 3) show that, the surarm pasanters as at lunction of $(\mathrm{k})$ in SFotle and

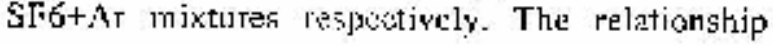

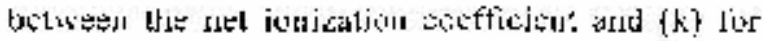
two mixture gases are linear at $\mathrm{E}$ ip $=50 \mathrm{~W} /(\mathrm{cm} . \mathrm{cor})$ as. show in Fiz-(2f) and (it). From the point at which the ner ionization cosfïcicent is cqual zenc, it wan to wiluced the (E;p)., value at ary value of (k).

Fig.(2) and (3) also shown that, the mothility, drilt velocity. diffusinn enefficiems and meall electron sucrigy dis a lintetion of (k) at E'p-60V)(Lm.krr) tor SFGite and SFG+Ar mixtures respectively. It is afpear trolu clese Jigur'a the behavios of thost ztyarn parameters are the sume. For example, for $k<4.4$, these jarameters decacasis atd lür $k>0.6$ they are

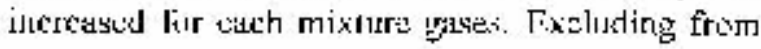

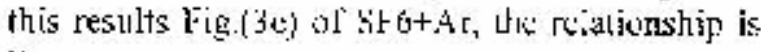
lineasr.

Fig.(4) and (5) show lhat, the swanu

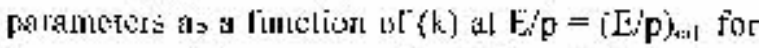
the sume mixlure gases, Jig. (4a) and $(5 n)$ show that, the (E'pilat as a funcioun of (k) lior two mixlure yazes. It appens thom this figure the

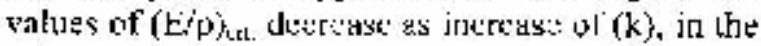
ather words, whos irecressing lhe percentrige of 11 e or Ar gakes the tucakdown heppens carly. rig. (Ab, $4,4, c, i)$ atd $(5 b, c, \downarrow, c, l)$ are lound from the Jijg $(4 a)$ and $\left(\varsigma_{n}\right)$.

In Fing.(4i) and (5b). the mean electron energy is a function of $(\mathrm{k})$ are constant at $\mathrm{E} / \mathrm{p}=$ (E/p)... For lwo mixture ydses. From this result and bocause of the dependence of mean encroy on discribution function only. versy iusporlint conclusion, that the distrikution nitnetion ar $(\mathrm{F} / \mathrm{p} / \mathrm{i})_{\mathrm{s}}$ is a constant tor any value of $(k)$. This is very cleir tiom the Fig. (6a. b), which is explain the hehaviour of distriturion finction at (E:F) as a

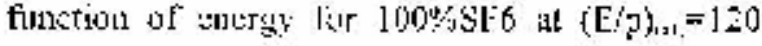

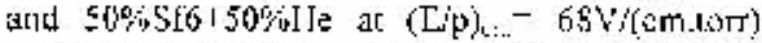

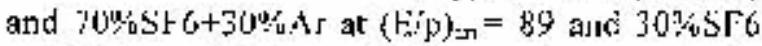

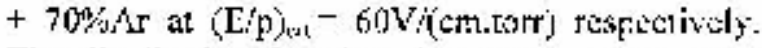
The distribution functions in Fig. $(6 \mathrm{a}, \mathrm{b})$ are very consistent, but the tonsistent is slowly shifted when deals with pure gess ar (E'p) as shown in ifig. $(6 \mathrm{c}, \mathrm{d})$.

The beluavior of mean electron enerey differs from other paranieters because the racas energy depcisds on the distribulion function only but othes paramitcrs are depend on the data of ctoss-scetions in addition of distributios tunction. This conclusion can hely. us ro solve Bollzmann

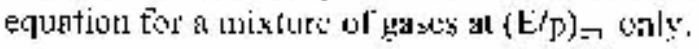

\section{Conclnsion}

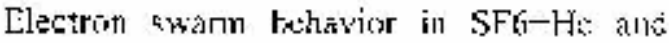

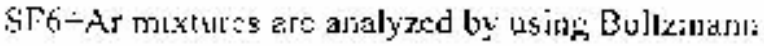


equation method which depends on the Biy_sig programs. The result of Eallemann equation analysis show that the providing set of crosiscetions gives tlic values of stwarm pasameters such ats ionization, net ionizstion and diffusion coefticitur : molvility and mcan energy tis $\mathrm{SF} 6+\mathrm{H}:$ and $S \mathrm{~F} \sigma+A \mathrm{~A}$ urixtures. Also, all these parautetes; evaluated at $L_{p}^{\prime}=(\mathrm{EPp})_{\mathrm{ces}}$. It is fount that, the mean energy lor these nixcure gases as a fiuction of $\mathrm{k}$ is wonstant at ( $\mathrm{E} / \mathrm{p})_{\mathrm{kn}}$. One of $\mathrm{vcry}$ implestent result that, the distriburion fusetion of thesc mixture gases are equal an (E'pj.... This rosult can cnable us to solve Bulamsns equation lis reixture gasws at $(\mathrm{H} / \mathrm{P})_{\mathrm{m}}$. only at any valuc of $(\mathrm{k})$ if the values of $(\mathbf{E} / \mathrm{p})_{\mathrm{rr}}$ of mixhurs gases are presented

\section{References}

[1] H. Itol, T. Matsumura, K. Satuh, H. Thate, Y Nakao and $H$. Tagaslira, "Electron transpowit coeflicients in SF'6", J. Phys. T3: Appl. [2hys. Vol. 26 (1993) pp. I9/5-1979.

[2] Y. Qiu, X. Ren and X. Weng, "The dislestrio strength of $\mathrm{SF}$ fis and neol gas mixturest, 1 . Pfrys. D: Appl. Phys, Vol. 21 (1988) pp. 65\%698.

[3] D. M. Xiao. T., L. Zhu and X. Guung, "F.Icetrou swairm paralueters in SFG and Kryputu gas mixtures", 」pn. 1. Appl. Hlys., vol. 10 (2601! pp. L203-I.20.5.

[4] N. II. Malik and A. H. Qureshi, "A revice o." electricnl brealidokn in mixtures of $\$ \Gamma 6$ and

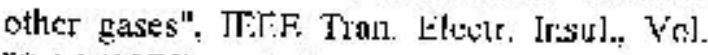
EJ-14 (1979) pp. 1-13.

[5] R. T. Van Brust, "Common paramelerizations of electron transport, collisios cruss sectjun, and dielectris strength dola for binary gas mixtures". J. Appl. thyss., Vol. $61(1987) \mathrm{pp}$. $7773-1786$

[6] I. J. Morwcii and J. D. Craggis, "lwiization and atlachment and breakdown micasurements in mixtures of $5 \mathrm{H} 6$ wich helium, argon and hydrogen": Prow. Ol' 12 $2^{\text {th }}$ Interna. Cons. nn pheromena 1 lonized Gases, $(1975)$ pl, 272.32 .

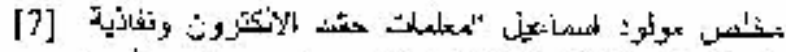

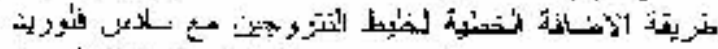

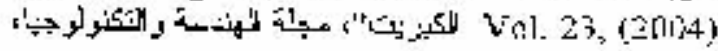
pp. $168-176$.

[\$] L. C. Pitchford, S. k. Oneil and j. K. Kuinbles, "Fxtended bollzmann analysis of electron: swa'ts txperiments", phys. REV, Vol. 23 (1981) p. 294-303.

[9] A. S. Husauni, R. R. Abdulla and M. M. Ismiti, "Effeut of the reduced stctric Jield strenglh on drifting clectron swarns in SF $6^{\prime \prime}$, Eng. And Texturwlugy, Vol. 22 (a)

[10] J. P. [keuf, Plyys, " Namerical moded of rï

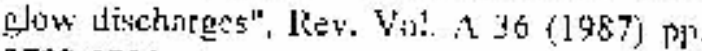
$2782-2790$.

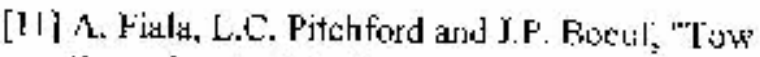
dimensional hybrid model of inw-pressure

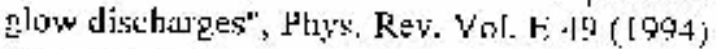
pp. $5607-5616$.

[i2] M. Il. Hutgles, "Electron energy Jistribition fimctions and transport cocfficierno in kelum and neon", J. Phy̌s. B: A. Mol. Hys., Vol. 3 (1950) pp. 1544-155].

[13] [T. Itoh, M. Shirmouma and H. Tasascira, "Boltzusuru tequation analysis of the electicti इжsarsn dewelopment in $\mathrm{S} F \mathrm{~F}$ and nitrugen mixtures".J. Ptyys, D; Appl. Phys., Vol. 13 (1980) pp.1201-1209.

[14] Vf. Shicrocisma fand H. Tagashiri, "Mcasurement of the ionizition snd atlichment coffficient is SFti and to:lius mixtures", 3. Phys. D: Appl. l'lyys., Visl. if (1985) pp. 128?-1291.

[IE] J.. F. Kline, D. K. Dayies. C. L. Chen and $r$, J. Chantry, "Dielectris properties of SF is aAkl SH' mixtures predicter frum busic data": J. Appl. Plys. Vol. $50(1979)$ pp. 678\%-67\%(i,

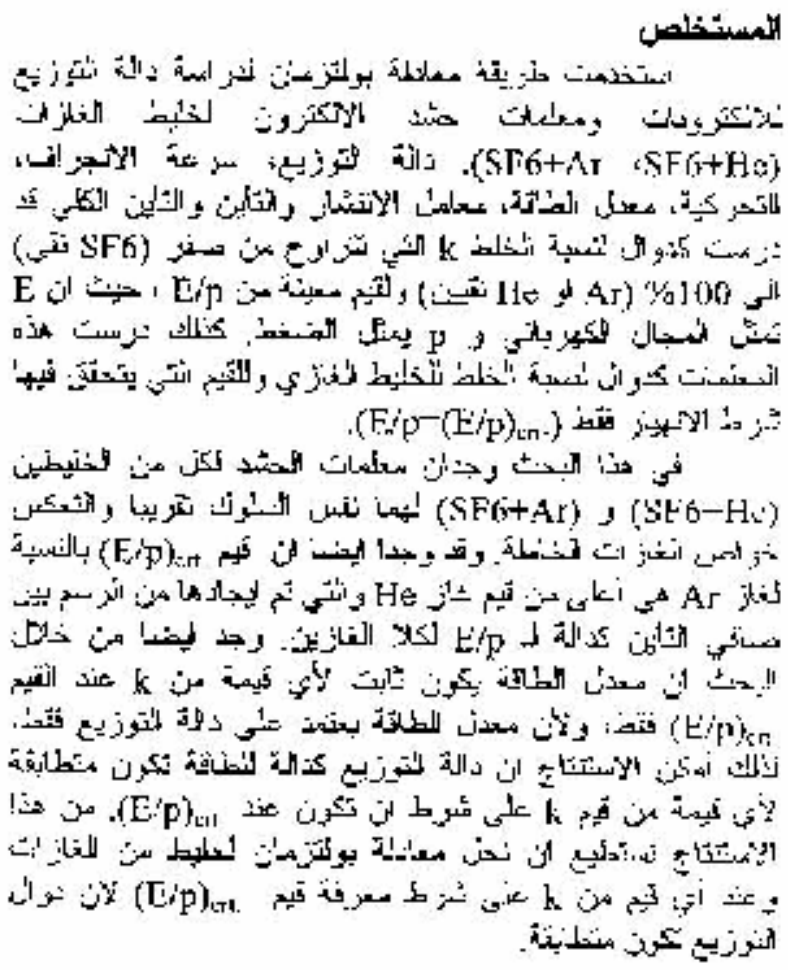



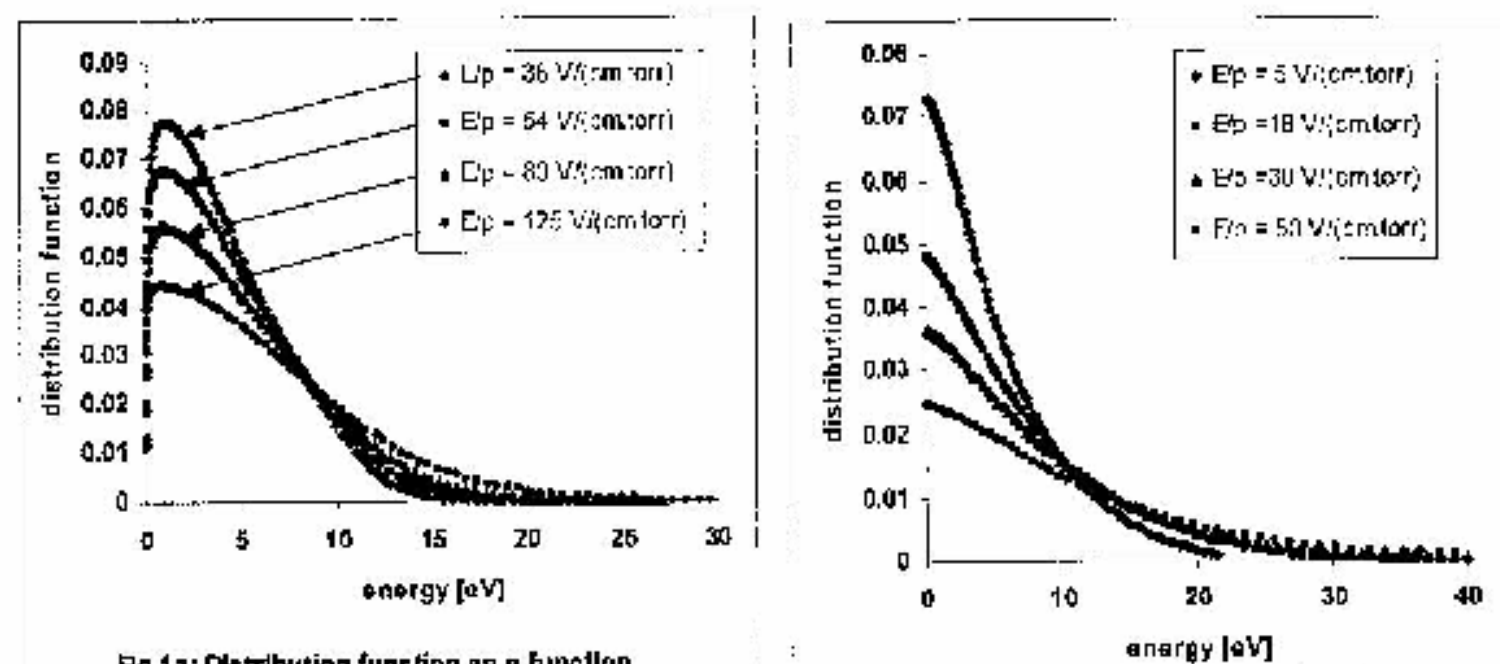

FG-1 2: DAstribution tunction ag a kunatlan of anergy in sक

Fig. 1b: Clstributlan function az a function of energy in the

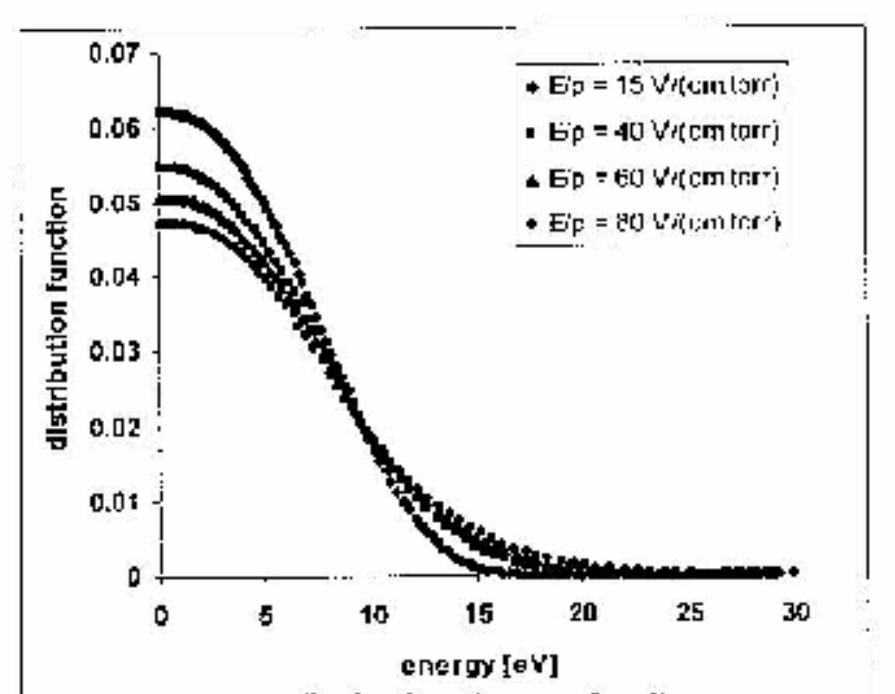

Fig. 1c: Diatribution functlon as a function of energy In Ar 


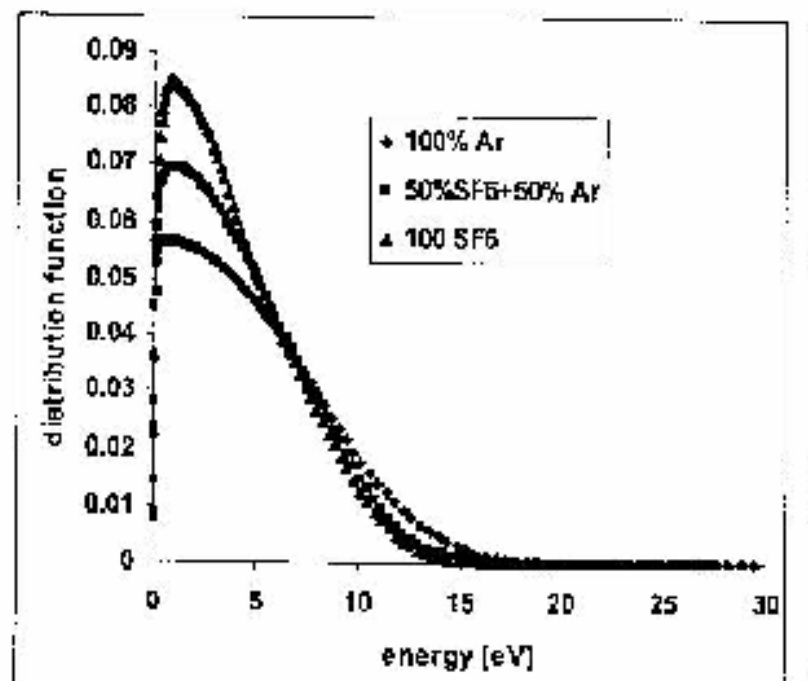

Fig.1d:dlstribution function as a functlon of enrgy for SF6+Ar mlxtures at $E / p=30$ Vi(cm.torr)

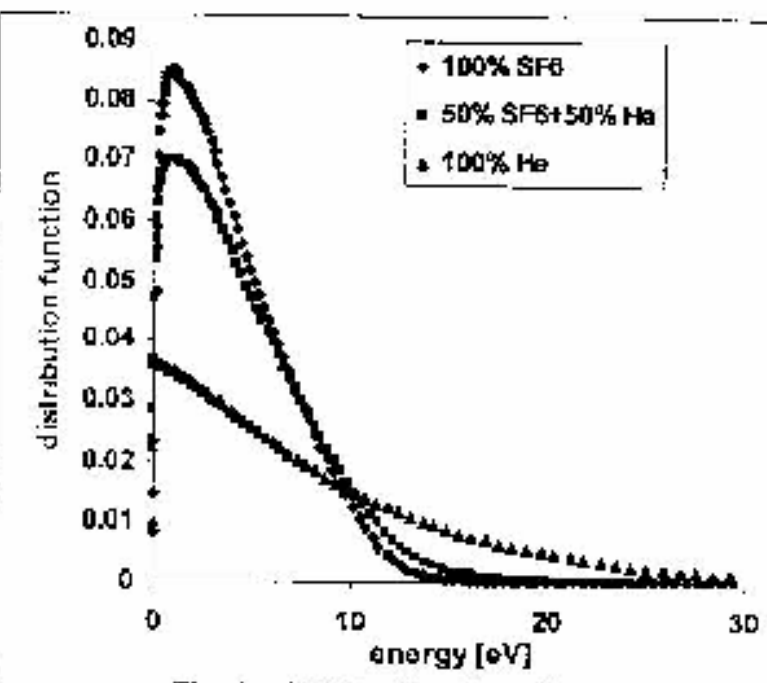

Fig.1e:dlatribution function ae a function of anergy for SF $4+$ Ho mixtures at E $p=3$ a

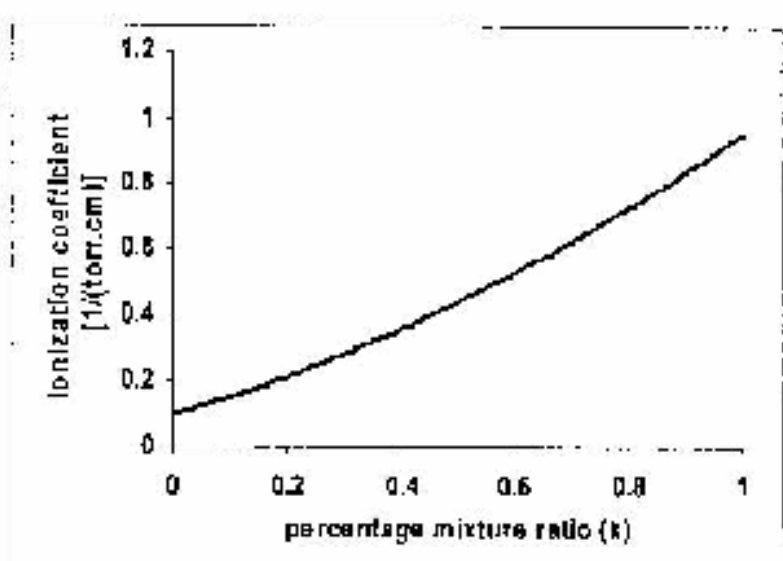

Fig. Za: lonization coenicient ab a function af percentage mixture ratio (k) in SFG+He mlxturegat E/p = 60 V/(cm.torr)

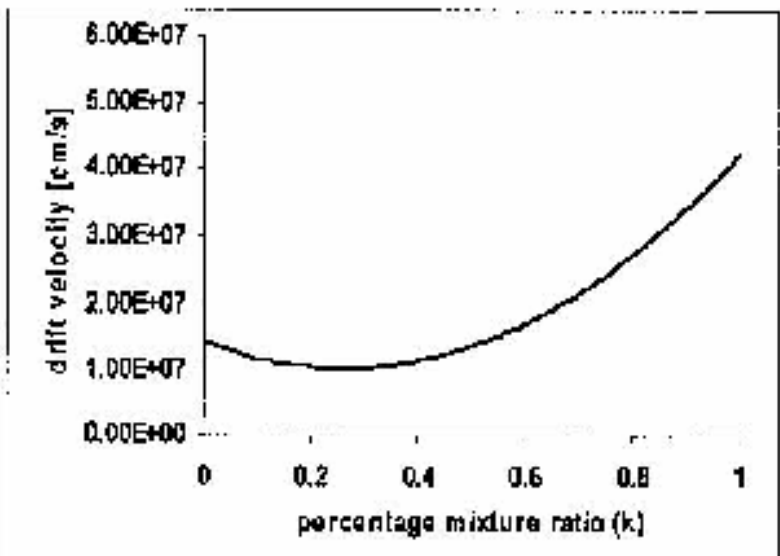

Fg. 26:Drifi yolocity as a furtctlor of

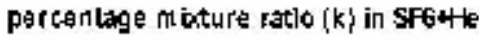
m Ixtures at $B p=60$ Wilcm torr)

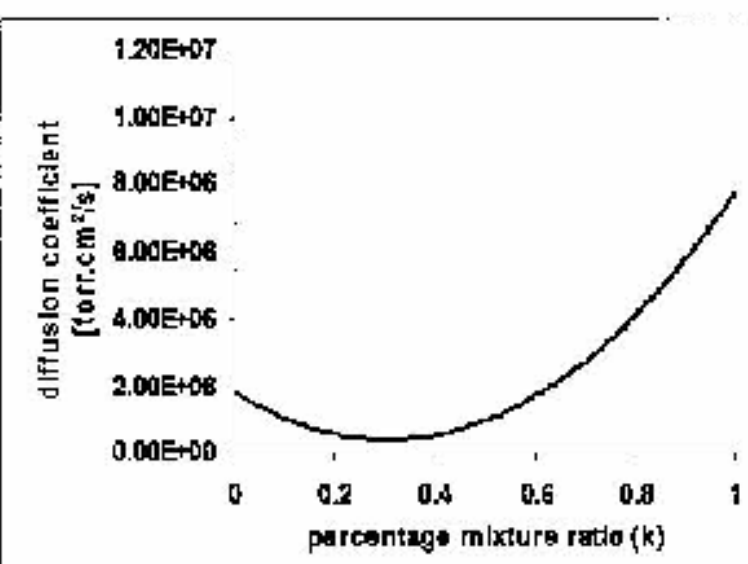

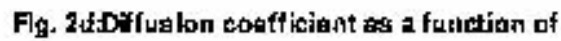
parcentage mlature rätlo \{k\} ln SA

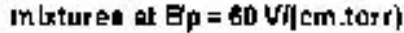



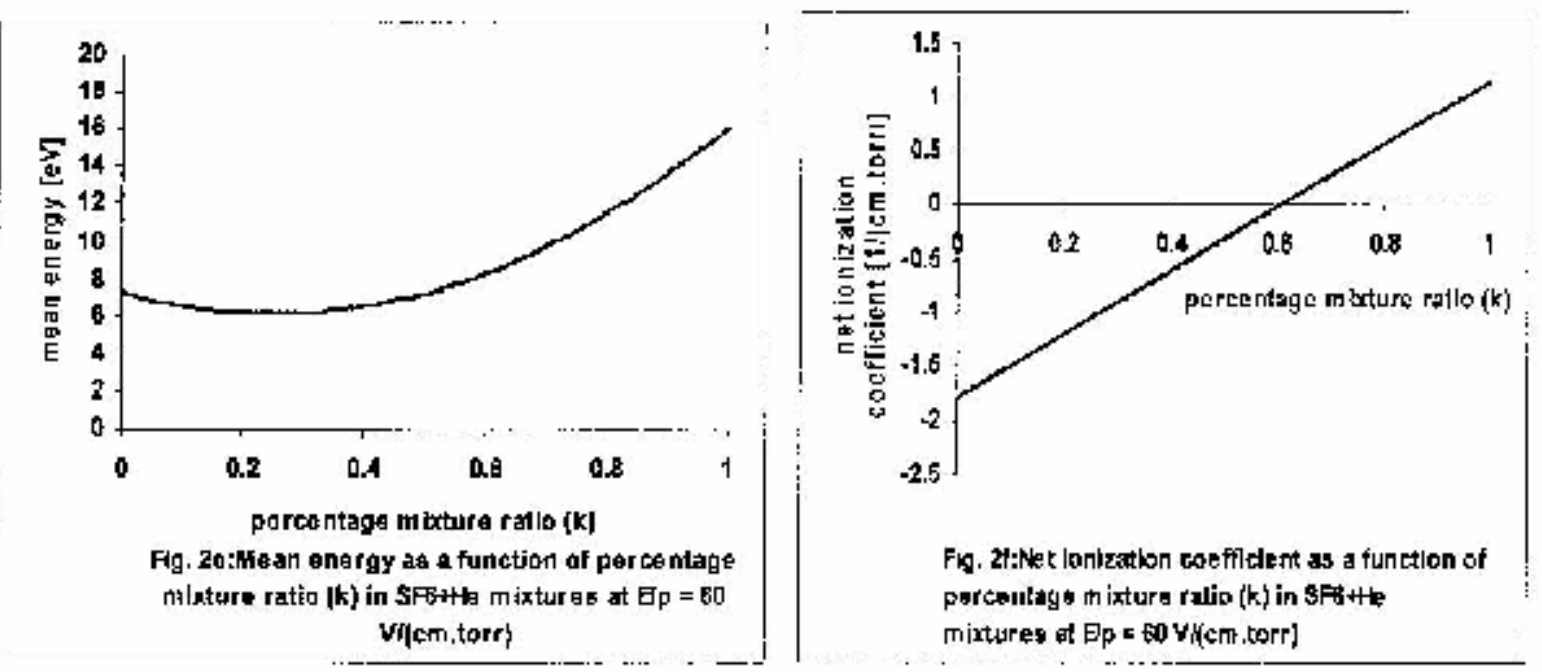

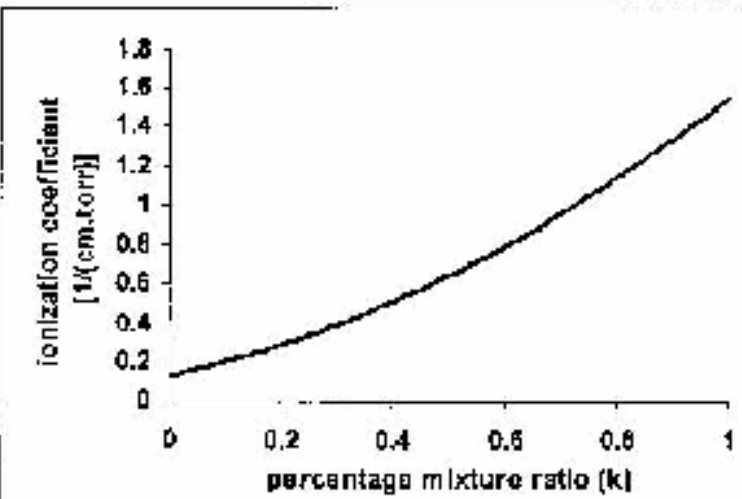

Fg. 9a: lonizatian calfflcient as a function of percentago meture rat lo $\{k \mid$ in $5 F+A r$ m (xtures at Ep -60 V(, cm.torr)

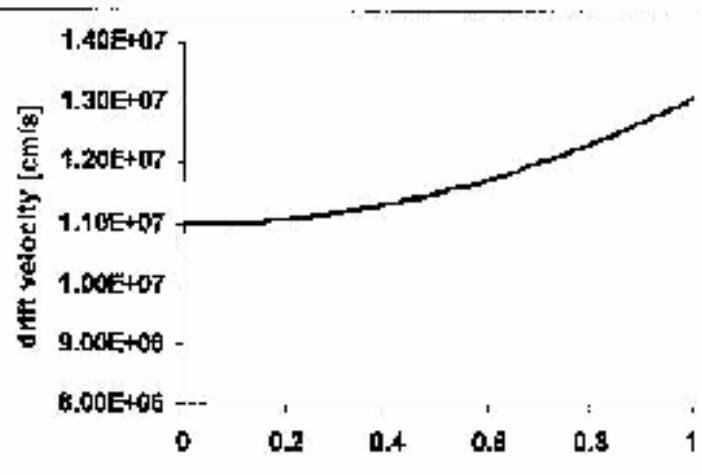

percentag $m\{x t$ ur t ratio (k\}

Fing. 3C: Drif velacity a y function of percontege mbtura ratio $(k)$ in $\$ F e+A r$ mintures at EP = 60 Wiam ,torr

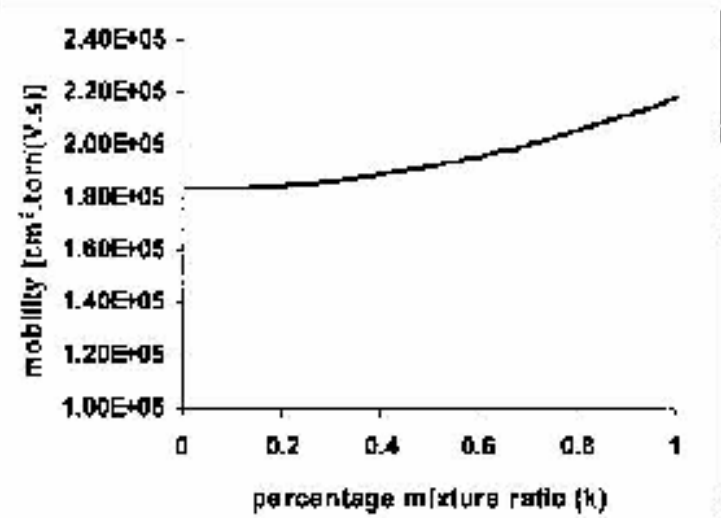

Fig. 3b: Mobility as a function of percentag a m lycture ratlo $\{k\}$ in SFb+Ar (m|xtures at E'p $x$ 60 Vi(cm.torr

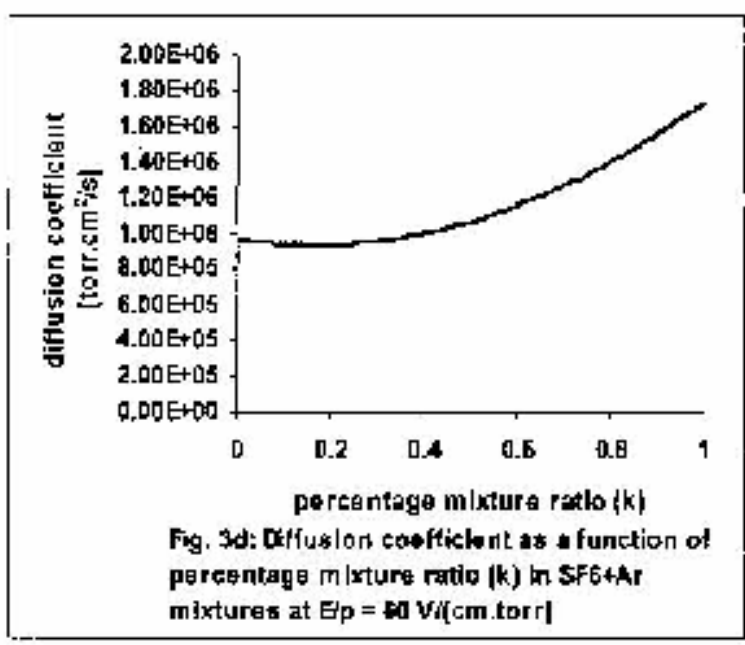



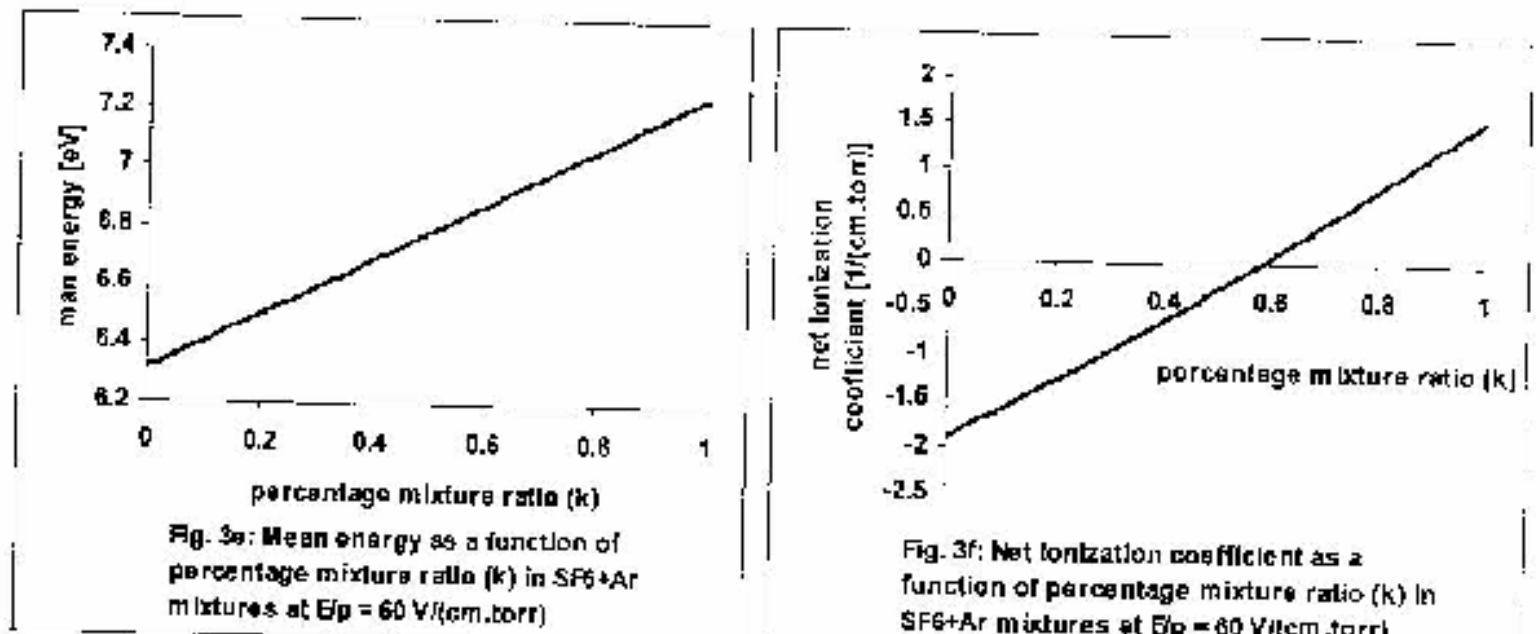

Fig. 3f: Net lonkatlon cosfific ie nt as a function or parcentage mixture ralio $(k)$ in SFG+Ar mixkures at $\mathrm{E}_{\mathrm{p}}=80 \mathrm{Vil} \mathrm{em}$.torr

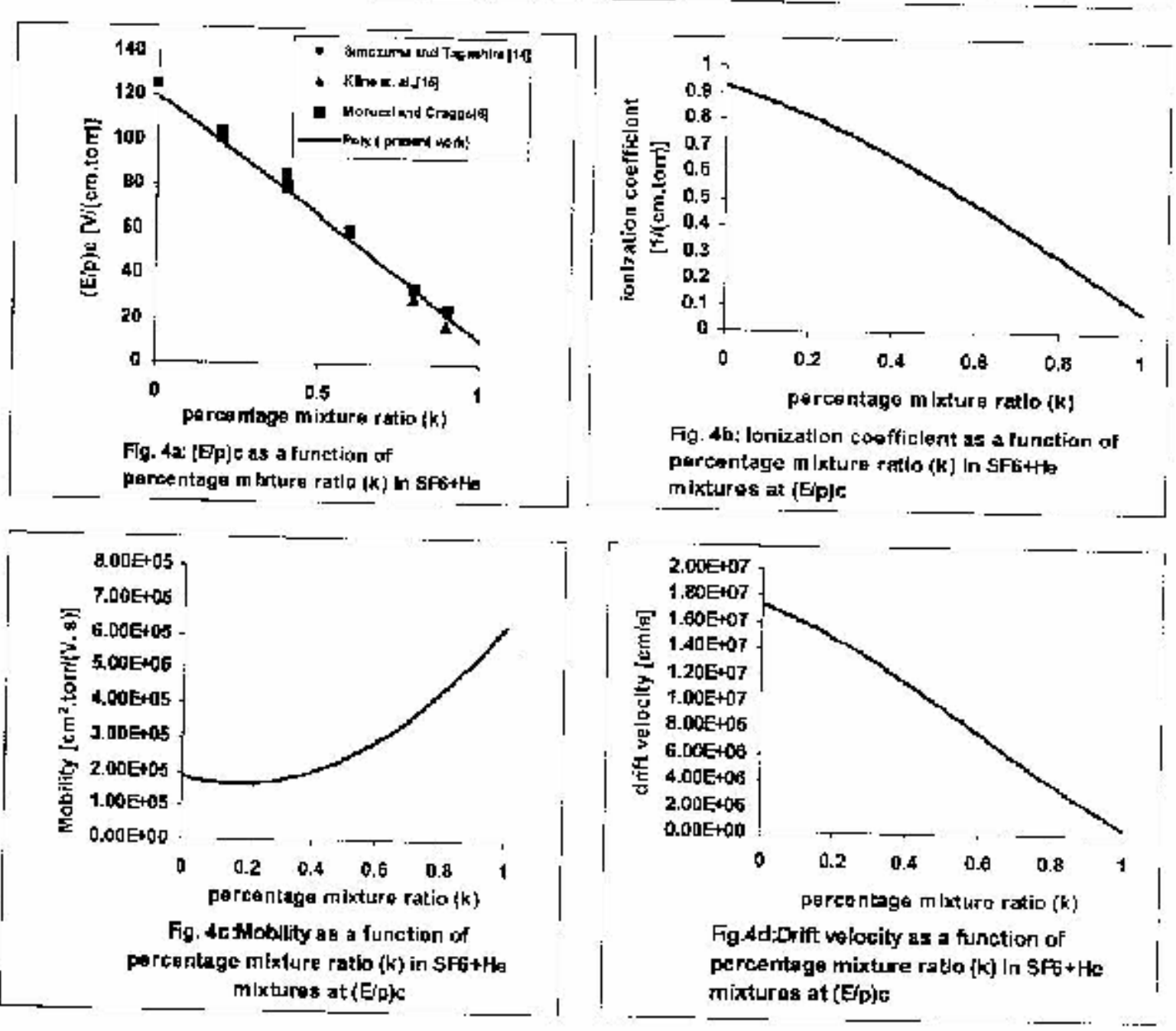



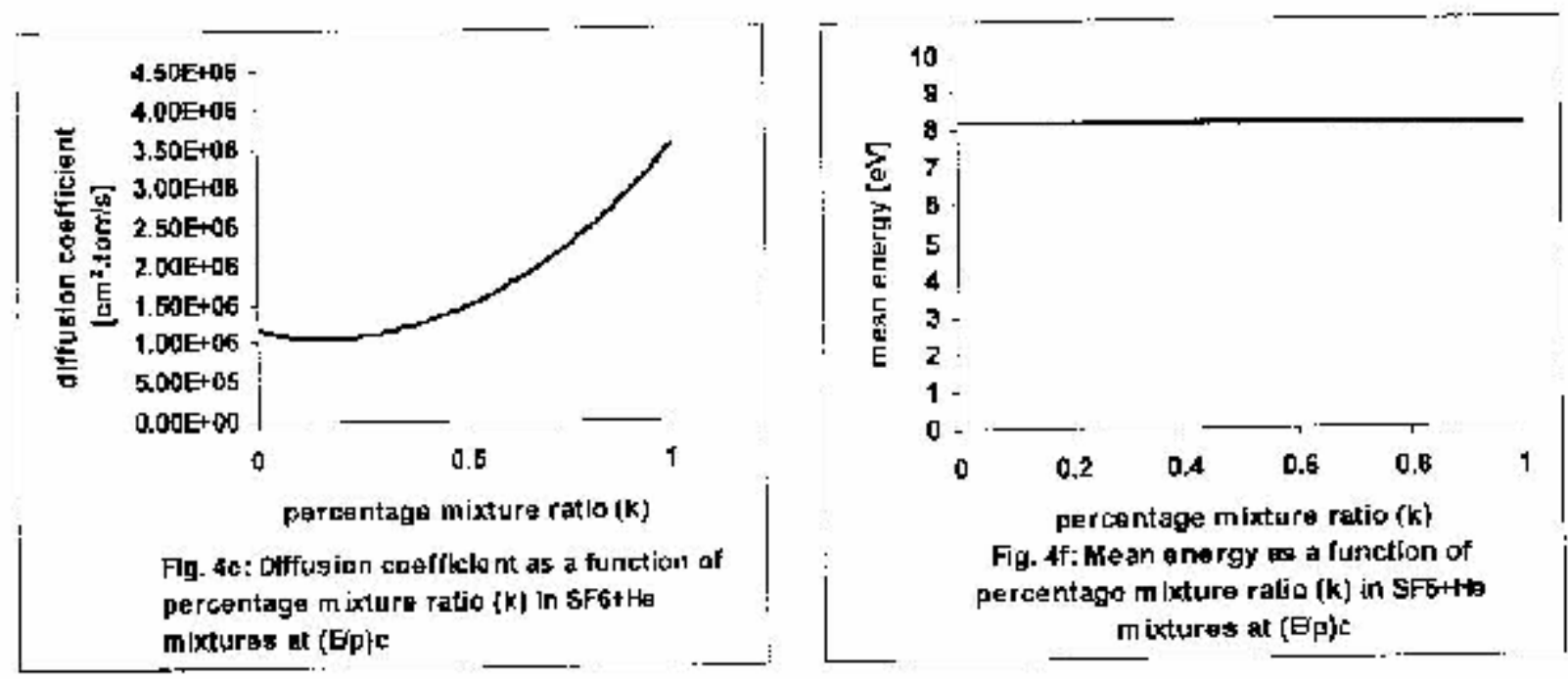

Fig. Ac: Diffugien caefilclo nt as a function af percentage mixturk ratio $\{k \mid$ in $\$ F 6+H e$ m|xturss at $\{$ Éppic

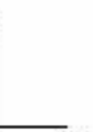

Fig. 4f: Mean energy wa a function of percentago m lxture ralio (k) in SFG Hto mixtures at (Ep)c

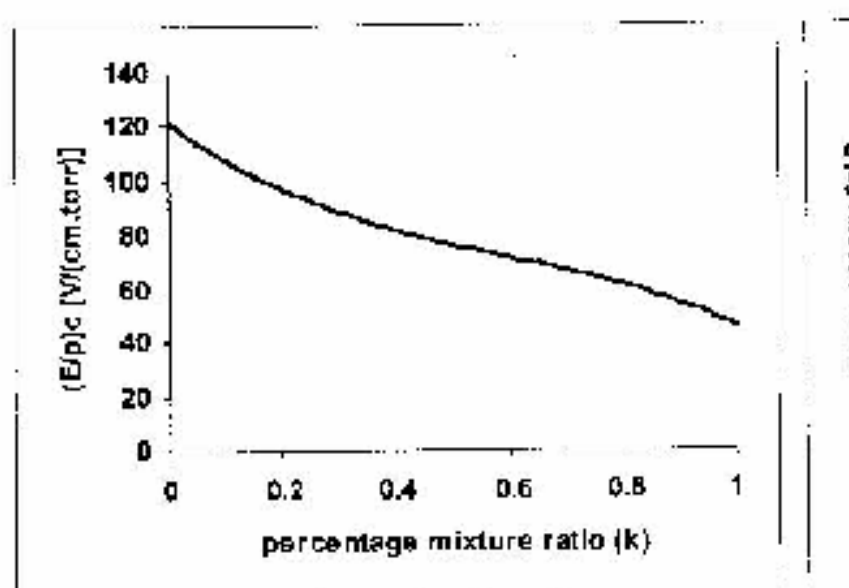

Fg. 53: (Ep) as a function of porcentage mixture ratio (kp in $5 F+$ +Ar

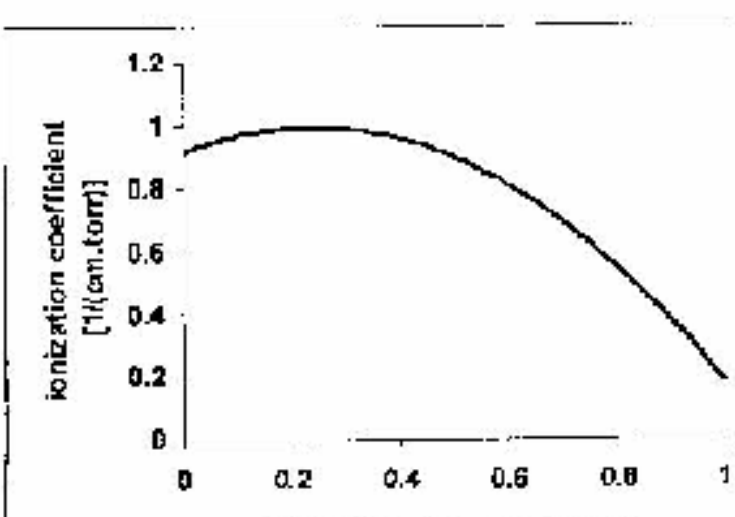

porcentage mixture ratio (k)

Fg. 5e: Ianizalion coofficient as a function of parcentagk mixtura rakio (k] In SFit,r mixtures * $(\theta, p)$

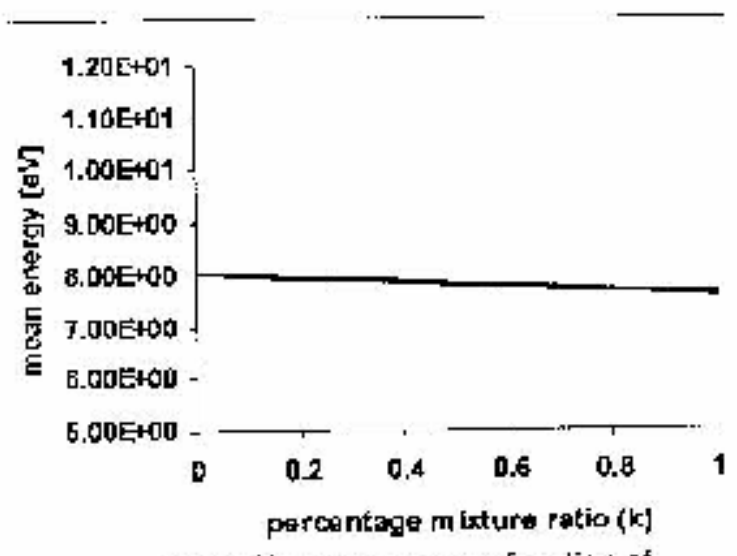

fg. 5b:Nesan energy as a function of percantage mlxture ratio (k) in SFitAr mixtures at $(E p)\}$

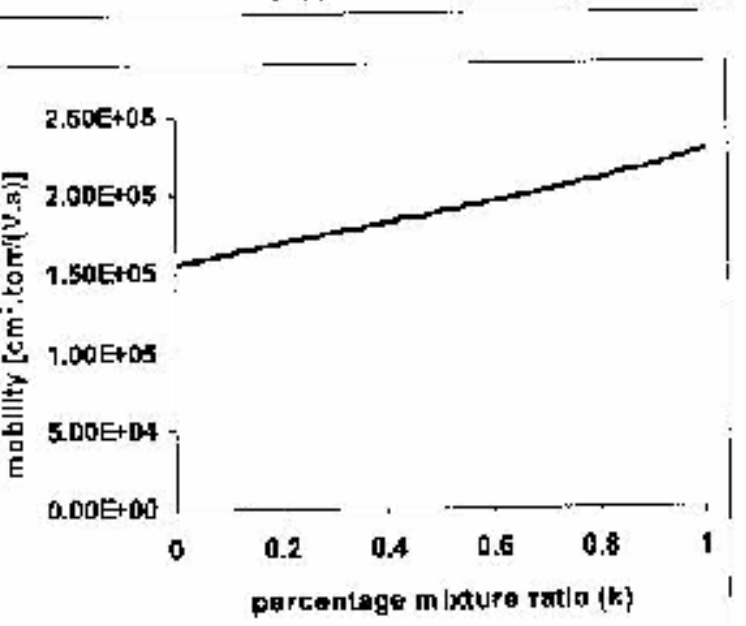

Fiy. Sd: Moblfity as a function of poresentege mixture rat lo (k) ln \&Fs+Ar mixlurts at (E'a)c 


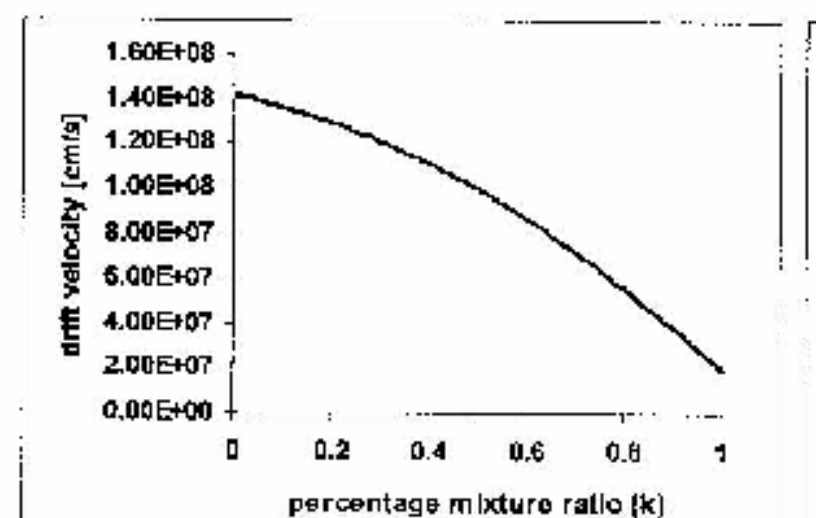

Fy. 6oxrlft volocity as a function of percentage mixture ratio $[k]$ in SFG+Ar mixtures at (E)phe
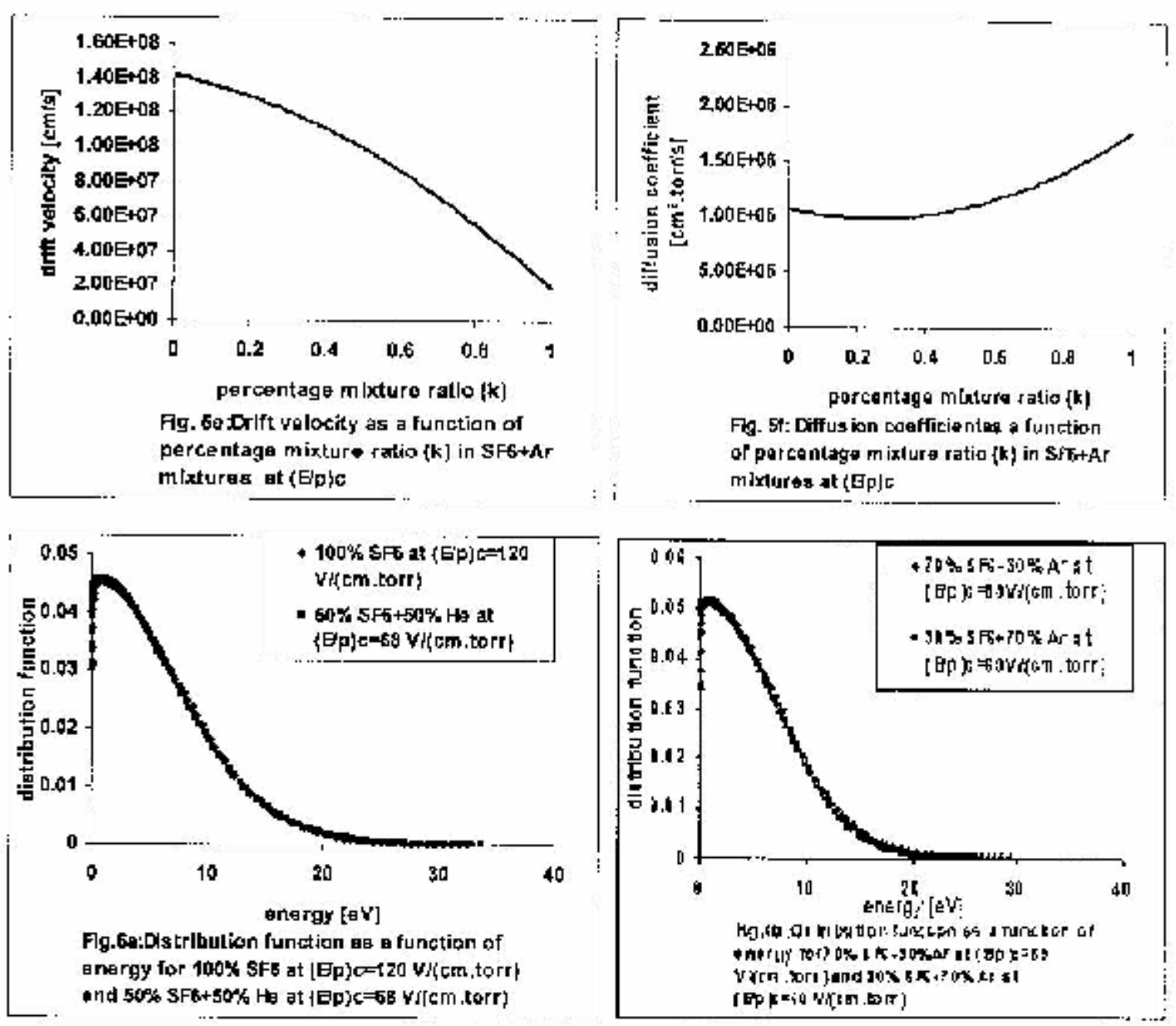

Flg.6a:Distribution function as a function of energy for 100\% SFE at [Bp]c్-20 V/(cm, torr)

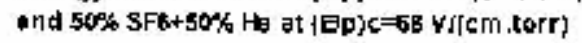
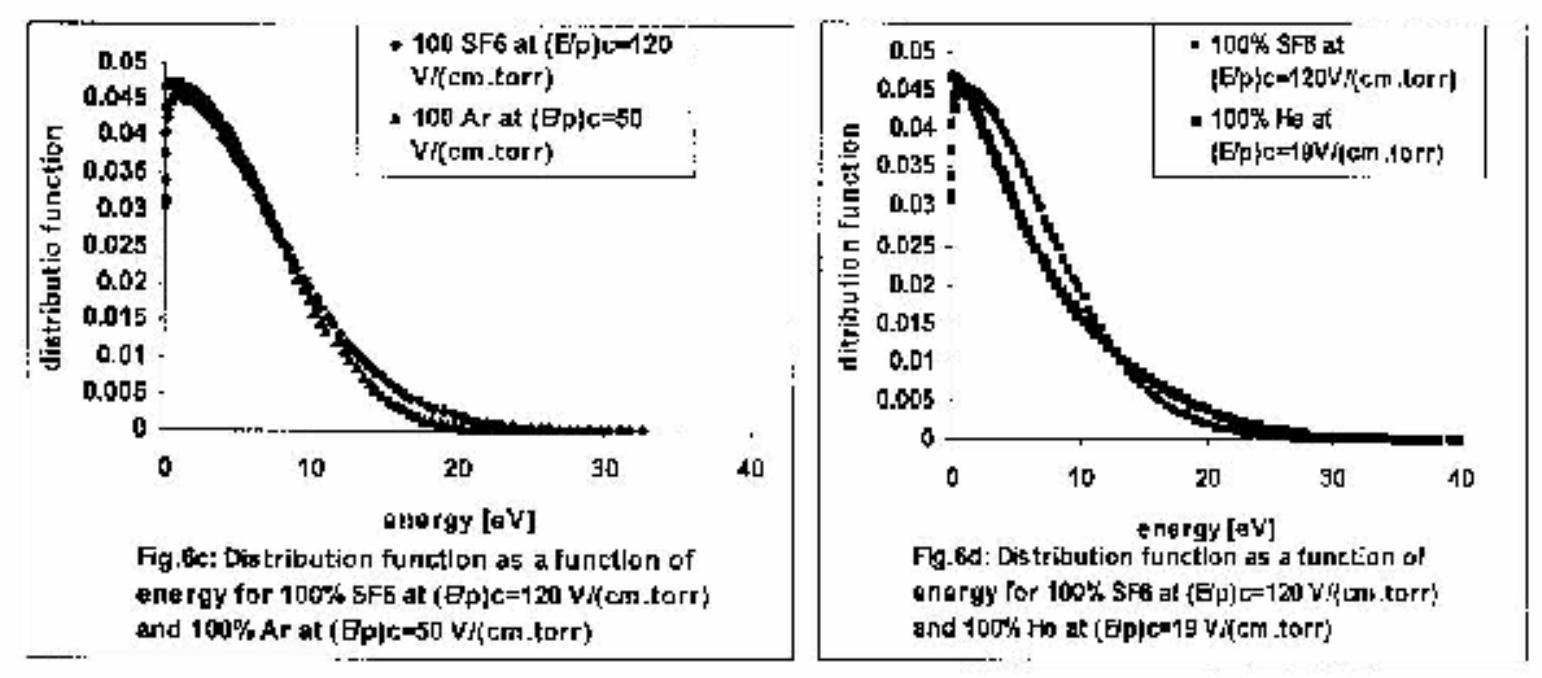